\title{
NATIVE MICROBIOTA AND ARBUSCULAR MYCORRHIZAL FUNGI ON GROWTH OF Paspalum millegrana SCHRAD ${ }^{1}$
}

\author{
JOHNY DE JESUS MENDONÇA ${ }^{2}$, LARISSA DE SOUZA GOIS ${ }^{2}$, JACILENE FRANCISCA SOUZA SANTOS ${ }^{2}$, \\ TAMIRIS APARECIDA DE CARVALHO SANTOS ${ }^{2}$, FRANCISCO SANDRO RODRIGUES HOLANDA ${ }^{2}$, REGINA \\ HELENA MARINO ${ }^{2 *}$
}

\begin{abstract}
Paspalum millegrana grass is a member of the family Poaceae native to the Americas, whose interaction with native symbiotic fungi has not yet been reported. The objective of this study was to evaluate the interactions between the native microorganisms and arbuscular mycorrhizal fungi in the development of $P$. millegrana Schrad. The experimental design was completely randomized with seven treatments (control, without AMF; native microbial inoculant; native + UFLA05 Gigaspora albida; native + UFLA351 Rhizoglomus clarum; native + UFLA372 Claroideoglomus etunicatum; native + UFLA401 Acaulospora morrowiae, and a mix of all treatments). The substrate was autoclaved sand and coconut powder at 2:1, with eight repetitions. The variables analyzed were: mycorrhizal colonization, dark septate endophytic fungi colonization, number of mycorrhizal spores, dry shoot mass, dry root mass, root length and volume, number of tiller and mycorrhizal dependence. Mycorrhizal arbuscular fungi and dark septate endophytic fungi colonized $P$. millegrana. The sporulation of arbuscular mycorrhizal fungi associated with $P$. millegrana was influenced by mycorrhizal colonization, depending on the fungus-plant interaction. P. millegrana was responsive to native + UFLA05 and native + UFLA351. No correlation between tiller emergence and mycorrhizal colonization of $P$. millegrana was observed.
\end{abstract}

Keywords: Poaceae. Soil microbiology. Endophytic fungi.

\section{MICROBIOTA NATIVA E FUNGOS MICORRÍZICOS ARBUSCULARES NO CRESCIMENTO DE Paspalum millegrana SCHRAD}

RESUMO - Paspalum millegrana é uma poácea nativa das Américas, cuja interação com fungos simbiontes nativos ainda não pode ser encontrada na literatura. $\mathrm{O}$ objetivo deste trabalho foi avaliar a interação entre microrganismos nativos e fungos micorrízicos arbusculares no crescimento de $P$. millegrana Schrad. O delineamento experimental utilizado foi inteiramente casualizado composto por sete tratamentos (controle, sem inoculação; inoculante microbiano nativo; nativo + UFLA05 Gigaspora albida; nativo + UFLA351 Rhizoglomus clarum; nativo + UFLA372 Claroideoglomus etunicatum; nativo + UFLA401 Acaulospora morrowiae e mistura de todos tratamentos), em substrato à base de areia autoclavada e pó de coco, na proporção de 2:1, com oito repetições. As variáveis analisadas foram: colonização micorrízica e por fungos endofíticos, número de esporos micorrízicos, matéria seca da parte área e da raiz, comprimento e volume da raiz, número de perfilhos e dependência micorrízica. O $P$. millegrana foi colonizado por fungos micorrízicos arbusculares e por fungo endofítico "dark septate". A esporulação de fungos micorrízicos arbusculares associados ao $P$. millegrana foi influenciada pela colonização micorrízica, a depender da interação fungoplanta. O P. millegrana foi responsivo a inoculante nativo + UFLA05 (Gigaspora albida) e nativo + UFLA351 (Rhizoglomus clarum). Não houve correlação entre a emissão de perfilhos e a colonização micorrízica.

Palavras-chave: Poaceae. Microbiologia do solo. Fungos endofíticos.

\footnotetext{
*Corresponding author

${ }^{1}$ Received for publication in $05 / 06 / 2017$; accepted in 01/29/2019.

Paper extracted from the scientific initiation work of the first author.

${ }^{2}$ Departament of Agronomic Engineering, Universidade Federal de Sergipe, São Cristóvão, SE, Brazil; mendonça.johny@yahoo.com.br ORCID: 0000-0002-7690-6234, lary18gois@gmail.com - ORCID: 0000-0003-2134-0509, jacilenesantos_14@hotmail.com - ORCID: 0000-0001-5109-3663, tamiriscarvalho12@gmail.com - ORCID: 0000-0002-7804-7533, fholanda@infonet.com.br - ORCID: 0000-00016812-6679, rehmarino@hotmail.com-ORCID: 0000-0002-7295-3746.
} 


\section{INTRODUCTION}

The Paspalum millegrana Schrad is a native grass plant of the Americas, characterized by robust clumps and deep rhizomes. It has been reported in Rio Grande do Norte (OLIVEIRA et al., 2013), Pernambuco (MACIEL, OLIVEIRA, ALVES, 2009) and Sergipe (MACIEL; ALVES, 2011) in Brazil.

The genus Paspalum is characterized by its rapid regeneration capacity as well as its ability to grow in areas of low fertility, and contributes to soil conservation, besides serving as animal food (LONDE; BITAR, 2011; CARAMASCHI et al., 2016).

The rapid development of Paspalum grass in the degraded land areas may be associated with the soil microbiota, such as arbuscular mycorrhizal fungi (AMF), which increases the dry mass in plants, due to the formation of fine roots responsible for the absorption of water and nutrients for plant metabolism (JALONEN et al., 2013). In addition, mycorrhizal fungi also secrete the glycoprotein called glomalin, which, together with the action of extraradicular hyphae, forms microaggregates of soil particles, an important factor in soil conservation (RUBIN; STÜRMER, 2015)

The AMF also produce structures such as the appressorium, which are important in the fungusplant interaction, because they are essential for initial colonization; vesicles, which have a reserve function, mainly of lipids; arbuscules, which are structures considered as sites of fungus-plant symbiosis; and spores, responsible for the dissemination and survival of the mycorrhizal fungi in free-living conditions (MIRANDA, 2008).

The AMF-Paspalum interaction has been described only for P. natatu species in China (CUI et al., 2015), $P$. maximum and $P$. notatum in Colombia (MONROY et al., 2013), P. scrobiculatum in India (CHANNABASAVA; LAKSHMAN; MUTHUKUMAR, 2015) and P. dilatatum "Cousin" in Argentina (CAVAGNARO et al., 2014). However, no reports were found on the mycorrhizal interaction with $P$. millegrana, as well as the association of this grass with the native microbiota.

The dark septate endophytic fungi characterized by the presence of septate and melanized hyphae may stimulate the growth of certain plant species by increasing the availability of nutrients (RIBEIRO et al., 2011), as well as promoting the tolerance of plants to high temperature and water stress (BARROW; OSUNA, 2002), conditions frequently found in the Northeastern region of Brazil. Santos and Varavallo (2011) also reported the induction of the plant defense system against certain pathogens by dark septate endophytic fungi, which can reduce pesticide use. However, Yan et al. (2015); Uma et al. (2012) reported that dark septate endophytic fungi may stimulate or inhibit the growth of other microorganisms, which may compromise AMF-host plant symbiosis. Thus, the objective of this work was to evaluate the interactions between native microorganisms and arbuscular mycorrhizal fungi on the growth of $P$. millegrana.

\section{MATERIAL AND METHODS}

This study was performed in Departamento de Engenharia Agronômica, of the Universidade Federal de Sergipe, located in the municipality of São Cristóvão, Sergipe, Brazil. The geographical coordinates are $37^{\circ} 06^{\prime} 20^{\prime \prime} \mathrm{W}$ and $10^{\circ} 55^{\prime} 51^{\prime \prime} \mathrm{S}$.

A completely randomized experimental design was used, comprising a cultivar of $P$. millegrana and seven treatments (control, without AMF; native microbial inoculant; native + UFLA05 - Gigaspora albida Schenck \& Smith, native + UFLA351 - Rhizoglomus clarum (Nicolson \& Schenck) Sieverd, Silva \& Oehl; native + UFLA372 - Claroideoglomus etunicatum (Becker \& Gerdemann) Wakler \& Schüßer; native + UFLA401 - Acaulospora morrowiae Spain \& Schenck and mixture of native and all UFLAs), in a substrate composed of autoclaved sandy soil and coconut powder at a ratio of $2: 1$, with eight repetitions.

The native arbuscular mycorrhizal was isolated from a collection of samples of the rhizospheric soil of $P$. millegrana obtained using a garden shovel. P. millegrana was cultivated in an experimental area situated on the right bank of the lower São Francisco river, in the municipality of Amparo de São Francisco (coordinates UTM 744,301,092 E / 8868.461.918 N), in Sergipe.

The soil of the collection area was classified as Flossic Neosol, composed of more than 90\% fine and very fine medium sand (HOLANDA; ROCHA; OLIVEIRA, 2008). In order to cultivate the native inoculant, soil samples with root fragments of $P$. millegrana and spores were stored in vessels previously disinfected with $0.5 \%$ sodium hypochlorite and stored at room temperature, without irrigation and without the host plant, for 20 days to stimulate sporulation.

The mycorrhizal isolates from UFLA (Universidade Federal de Lavras) were cultivated multiplied in a substrate containing autoclaved sandy soil in a ratio of 2:1 (autoclaved soil: mycorrhizal inoculum). The mycorrhizal inoculum consisted of sandy soil containing root fragments/spores distributed between two layers of the autoclaved culture substrate and sown to Urochloa decumbens. They were cultivated in a greenhouse equipped with sprinkler irrigation. After 60 days, in order to stimulate mycorrhizal sporulation, the shoots were harvested from grass plant and the irrigation was suspended for 20 days.

The seeds of $P$. millegrana were subjected to surface disinfection with $70 \%$ alcohol for 1 minute, 
$0.2 \%$ sodium hypochlorite for 1 minute and followed by three washes using autoclaved distilled water for 1 minute each. The disinfected seeds were individually transferred to a gerbox box containing autoclaved sand and moistened with autoclaved distilled water. The seeds were placed in an incubator maintained at $25 \pm 1^{\circ} \mathrm{C}$, with $8 \mathrm{~h}$ photoperiod. The sandy soil was moistened every two days with autoclaved distilled water in an aseptic chamber until transplanting. The germination rate of P. millegrana seeds was $28 \%$. At 15 days after sowing, the seedlings obtained from $P$. millegrana were collected, standardized for height $(2 \mathrm{~cm})$ and transferred to tubes, previously disinfected with $0.5 \%$ sodium hypochlorite for $20 \mathrm{~min}$, and containing autoclaved sandy soil and coconut powder $(2: 1)$. In between the two layers of the substrate (sandy soil and coconut powder), $50 \mathrm{~g}$ of inoculant containing 30 and 27 spores from the native strain and from UFLA, respectively, was added. In the control treatment, no microbial inoculant was added. The tubes containing the substrate, the inoculant, and the seedlings with different treatments were randomly placed in the greenhouse.

During cultivation, $2 \mathrm{~mL}$ of nutrient solution per tube with $15 \%$ nitrogen and $14 \%$ potassium oxide was applied weekly. On the $30^{\text {th }}$ day of cultivation, the fertilizations frequency as change biweekly with the application of $3 \mathrm{~mL}$ of a solution prepared with $10 \mathrm{~g} \mathrm{~L}^{-1}$ of commercial fertilizer consisting $13 \%$ total nitrogen $(\mathrm{N}), 5 \%$ phosphorus $\left(\mathrm{P}_{2} \mathrm{O}_{5}\right), 13 \%$ potassium $\left(\mathrm{K}_{2} \mathrm{O}\right), \quad 5 \%$ sulfur, $1 \%$ calcium, $1 \%$ magnesium, $1 \%$ iron, $0.15 \%$ zinc, $0.08 \%$ manganese, $0.04 \%$ boron, $0.05 \%$ copper and $0.005 \%$ molybdenum, described on the commercial product label.

The variables evaluated were: colonization and mycorrhizal structures (hyphae, appressorium, arbuscules, vesicles and spores), presence of dark septate endophytic fungi, number of mycorrhizal spores, plant height, root length and root volume, dry shoot mass, dry root mass, and the number of tillers of $P$. millegrana plants after 90 days of inoculation and transplanting.

Mycorrhizal colonization (MC) was evaluated after 30, 60 and 90 days of inoculation using the intersection method according to Giovannetti and Mosse (1980) with modifications. In order to do this, root fragments were stained with Tripan blue and placed on a glass slide $(5 \mathrm{~mm} \times 5 \mathrm{~mm})$ containing grids. The slides were examined for colonization and the presence of mycorrhizal structures (hyphae, appressorium, arbuscules, vesicles and spores) with the aid of a microscope at $400 \mathrm{x}$ magnification. The percentage of $\mathrm{MC}$ was determined by $\mathrm{MC}(\%)=$ ((TNCF) / (TNF) x 100), where TNFC - is the total number of colonized fragments, and TNF - refers to the total number of colonized and uncolonized fragments. The percentage of mycorrhizal fungi (Hiphae - H, apressorium - Ap, vesicles - Ve, arbuscules - Arb and spores - Spo) observed during the evaluation of the mycorrhizal colonization of selected root fragments was determined by MC (\%) $=((\mathrm{MFSN}) /(\mathrm{TNCF}) \times 100)$ where MFSN - is the mycorrhizal fungal structure number and TNFC refers to the total number of colonized fragments.

The dark septate endophytic fungi present in the root fragments were identified based on the melanized and septate hyphae (RIBEIRO et al., 2011). The classification of the occurrence of this endophytic fungus was: $(-)$ absence and $(+)$ presence of endophytic. The frequency of endophytic fungus detected in the treatments, was considered based on the presence in the number of repetitions: $(+)$ present in one repetition, $(++)$ present in two repetitions, $(+++)$ present in three repetitions and $(++++)$ present in four repetitions.

The number of spores of the mycorrhizal isolates in the $P$. millegrana culture substrate was determined using to the wet sieving methodology described by Gerdemann and Nicolson (1963).

Height plant and root length were determined using a standard millimeter ruler. Measurements were recorded from the tip of the plant. The dry shoot mass and dry root mass were determined by weighing the samples in semi-analytical balance. Drying of the plant material (shoot and root) was in a forced air circulation oven at $60^{\circ} \mathrm{C}$ for three days. The number of tillers was counted and recorded.

The root volume was determined by the principle of water displacement. To perform this measurement previously collected and washed roots, were transferred to a beaker containing a fixed volume of water $(0.4 \mathrm{~L})$. When roots were added, the volume increased and was recorded. Based on the difference between the initial and final volume, the root volume was determined in liters (L), for each treatment.

The mycorrhizal dependence of $P$. millegrana was evaluated on dry shoot mass, dry root mass, total dry mass, root length and root volume of roots and compared to the control (no AMF). Mycorrhizal dependence (MD) for variable was determined by MD $(\%)=([(\mathrm{MP}-\mathrm{CP})) /(\mathrm{MP}] \times 100)$, where MP value of the mycorrhizal plant value and $\mathrm{CP}$ - value of the control plant (without inoculation). The classification of mycorrhizal dependence was described by Machineski, Balota and Souza (2011), in which plants with values $>75 \%$ were classified as excessively dependent; 50 to $75 \%$ as high dependence; 25 to $50 \%$ as moderate dependence and $<25 \%$ as marginal dependence or does not respond to microbial inoculation.

The data was subjected to Analysis of Variance (ANOVA) and, in cases where there were 
significant differences, was used Tukey's test at 5\% significance level for comparison of the means. The mycorrhizal colonization data were $\arcsin ; \mathrm{x}$ transformed and the percentage of mycorrhizal structures, number of spores, dry shoot mass, dry root mass, and root volume were transformed by $\sqrt{x}_{\mathrm{x}}$. Statistical analysis (mean test, regression and correlations) was performed using the Assistat program.

\section{RESULTS AND DISCUSSION}

The mean number of spores of the mycorrhizal isolates tested was 141.7 in $50 \mathrm{~g}$ in the $P$. millegrana cultivation, and ranged from 83 to 275 spores in the treatments with native and native + UFLAs, but without significant difference between the mycorrhizal treatments, except between native + UFLA372 and native + UFLA401 (Table 1).

Table 1. Number of spores (NSP) of arbuscular mycorrhizal fungi isolates (native and UFLA), mycorrhizal colonization (MC), regression coefficient $\left(\mathrm{R}^{2}\right)$ and presence of dark septate endophytic fungi (DSE) with Paspalum millegrana for 30 , 60 and 90 days of cultivation.

\begin{tabular}{|c|c|c|c|c|c|c|}
\hline \multirow[t]{2}{*}{ Treatments $^{1}$} & \multirow[t]{2}{*}{ NSP } & \multicolumn{3}{|c|}{ Mycorrhizal colonization (\%) } & \multirow{2}{*}{$\mathrm{R}^{2}$} & \multirow{2}{*}{ DSE } \\
\hline & & 30 days & 60 days & 90 days & & \\
\hline Control & $25.3 \mathrm{c}^{2}$ & $10.0 \mathrm{bA}$ & $4.5 \mathrm{bA}$ & $0.8 \mathrm{bA}$ & $0.76^{* 3}$ & + \\
\hline Native $(\mathrm{N})$ & $164.3 \mathrm{ab}$ & $29.4 \mathrm{abA}$ & $41.3 \mathrm{aA}$ & $41.1 \mathrm{aA}$ & $0.99^{* *}$ & - \\
\hline $\mathrm{N}+$ UFLA05 & $122.7 \mathrm{abc}$ & $43.9 \mathrm{aA}$ & $30.1 \mathrm{aA}$ & $23.6 \mathrm{aA}$ & $0.79^{* *}$ & ++ \\
\hline $\mathrm{N}+\mathrm{UFLA} 351$ & $196.3 \mathrm{ab}$ & $14.3 \mathrm{abA}$ & $31.4 \mathrm{aA}$ & $15.6 \mathrm{aA}$ & $0.87^{* *}$ & ++++ \\
\hline $\mathrm{N}+\mathrm{UFLA} 372$ & $275.0 \mathrm{a}$ & $36.4 \mathrm{abA}$ & $31.0 \mathrm{aA}$ & $17.5 \mathrm{aA}$ & $0.93^{*}$ & +++ \\
\hline $\mathrm{CV}(\%)$ & 21.8 & & .3 & & & \\
\hline
\end{tabular}

${ }^{1}$ Treatments: Control (without AMF); Native (N): native microbial inoculant; N + UFLA05: native + UFLA05 G. albida; $\mathrm{N}+$ UFLA351: native + UFLA 351 R. clarum; N + UFLA372: native + UFLA372 C. etunicatum; N + UFLA401: native + UFLA401 A morrowiae; e mixture - all isolates UFLA; ${ }^{2}$ Means followed by the same lower case letter (column) and upper case (line) do not differ statistically by the Tukey test at $5 \%$ probability; ${ }^{3}\left({ }^{*}\right)$ significant at $5 \%$ and $(* *)$ significant at $1 \%$ probability.

Sporulation in the native and native + UFLA treatments inoculated in $P$. millegrana may be associated with the fact that this species belongs to the Poaceae family. Carneiro et al. (2012) reported that poaceaus and forage plants stimulate mycorrhizal colonization and the formation of propagules. In the control treatment, sporulation was observed (25.3 spores per $50 \mathrm{~g}$ ) and mycorrhizal colonization varied 0.8 to $10 \%$, even though no inoculation was performed. This is probably due to dispersion of spores by wind and/or irrigation. When, the native inoculants and native + UFLAs were used, colonization ranged from 13.3 to $43.9 \%$, but without significant difference between the treatments with inoculation. In all the treatments (with and without inoculation), the mycorrhizal colonization of $P$. millegrana was adjusted to the quadratic regression model, although there was no significant difference between the evaluation periods (Table 1).

In comparison, Channabasava, Lakshaman and Muthukumar (2015) observed that $P$. scrobiculatum inoculated with Rhizophagus (= Glomus) fasciculatus showed $60 \%$ colonization after 90 days. Cavagnaro (2014) cited 80.4\% colonization of $P$. dilatatum inoculated with a mix of Glomus species (G. mosseae, G. intraradices and $G$. hoi), but only after 5 months of cultivation. The mycorrhizal colonization values of $P$. millegrana obtained were lower than those reported for other
Paspalum species, probably due to the fungal-plant interaction and the cultivation time (90 days), which may be considered low.

During the evaluation of mycorrhizal colonization, the presence of dark septate endophytic fungi was observed in all treatments, except in the one containing the native fungi (Table 1). The fungi of the genus Alternaria, Acrotheca, Aspergillus, Fusarium and Penicillium were also found in the seeds, which depending on the species may be endophytic (AZEVEDO, 1998). However, it was not possible to identify the fungi with septate and melanized hyphae during the mycorrhizal colonization analysis, due to the lack of reproductive structures, which does not allow for confirmation of the dark septate endophytic fungi and validate if they were the same as those identified in the seeds. However, it was not possible to identify fungi of septate and melanized hyphae during the mycorrhizal colonization analysis, due to the absence of reproductive structures, which does not allow the conclusion that the dark septate endophytic fungi are the same as those identified in the seeds.

Yan et al. (2015) reported that dark septate endophytic fungi may stimulate or inhibit microbial activity in soil. In this work with P. millegrana, the presence of these endophytes was positively correlated only with the colonization of the plants in the control $(r=1.0 ; p<0.01)$, the presence of these endophytes could only be positively correlated to the 
colonization of the $P$. millegrana plants in the control. This phenomenon may be responsible for the rapid growth of Paspalum grass in the field and mask the effect of the native and native inoculants + UFLA, due to the influence of these endophytes on the primary metabolism of plants (DUPONT et al., 2015).

Another aspect to be considered is that the number of spores was not correlated to mycorrhizal colonization, except in the treatment with native + UFLA351, which had a positive correlation $(\mathrm{r}=0.98,0.1 \leq \mathrm{p}<0.05)$. The absence of correlation between sporulation and colonization was also cited by Carneiro et al. (2012) in another plant species and AMF. The positive correlation between sporulation and colonization observed in the native + UFLA351 treatment was also reported by Channabasava, Lakshaman and Muthukumar (2015) with $P$. scrobiculatum grass and $R$. fasciculatus fungus. Thus, the mycorrhizal colonization of $P$. millegrana does not guarantee increased sporulation of AMF isolates as this depends on the fungal-plant interaction, as also observed by Augé (2001) with $P$. notatum and the mycorrhizal fungi Acaulospora longula, Glomus mosseae, and Gigaspora margarita. The mycorrhizal colonization of $P$. millegrana in the control (without AMF) was characterized by the presence of hyphae, vesicles, spores, but without significant difference between the periods of evaluation, absence of arbuscules and appressorium. In the native inoculant, colonization was characterized by hyphae, vesicles, spores, arbuscules and appressorium. The percentage of hyphae reduced significantly with increase in the incubation period, while appressorium and arbuscules increased significantly in cultivation periods of 30 and 90 days. Further, in this treatment, the number of vesicles and spores remained constant during the growing period.

The $P$. millegrana plants inoculated with native + UFLA05 (G. albida) had mycorrhizal colonization comprising hyphae, vesicles, spores, arbuscules and appressorium, and an increase in culture duration had no influence on the formation of hyphae and spores. The percentage of arbuscules, however, increased between 30 and 60 days, while that of vesicles and appressorium significantly reduced between 30,60 and 90 days of cultivation (Table 2)

The presence of vesicles in the control in the native inoculant and in the native + UFLA05 ( $G$. albida) indicates that the colonization of $P$. millegrana was mainly by isolates belonging to the genus Glomus and/or Paraglomus, because this structure is unique to the Glomaceae family, which comprises these two genera and not in the genus Gigaspora (MONROY et al., 2013), as was the UFLA05 isolate.

In the native inoculant + UFLA351 (R. clarum) mycorrhizal colonization of $P$. millegrana, hyphae (31.9 to $61.4 \%)$, vesicles ( 0 to $16.5 \%$ ), arbuscules ( 0 to $17,8 \%$ ), spores (18.6 to $37.1 \%)$ and appressorium (0 to $14 \%)$ were present. A greater number of vesicles, arbuscules and appressorium was observed at 60 days than at 30 days (Table 2). The mycorrhizal colonization of $P$. millegrana with native + UFLA372 (C. etunicatum), however, was characterized by hyphae (15 to $28.7 \%$ ), vesicles (10.9 to $42.3 \%$ ), arbuscules $(0,0$ to $16.7 \%)$, spores $(5.0$ to $30.4 \%)$ and appressorium ( 0 to $21.0 \%$ ). The percentage of vesicles increased between 30 and 60 days of incubation, while arbuscules and appressorium were higher at 60 days in relation to the other evaluation periods (Table 2).

$P$. millegrana inoculated with UFLA401 (A. morrowiae) exhibited mycorrhizal colonization by hyphae (31.8 to $42.9 \%$ ), vesicles (11.4 to $34.8 \%$ ), arbuscules (0 to $9.0 \%$ ), spores (15.4 to $32.4 \%$ ) and appressorium $(0.0$ to $10 \%)$, but with no significant difference between the evaluation periods, except for the percentage of vesicles that increased significantly between 30 and 90 days. In the mixture treatment consisting of inoculation of $P$. millegrana with all mycorrhizal isolates (native + UFLA05 + UFLA351 + UFLA372 + UFLA401), colonization was by hyphae $(26.3$ to $51.0 \%)$, vesicles $(9.4$ to $27.1 \%)$, arbuscules $(0.0$ to $13.6 \%)$, spores (11.4 to $22.2 \%$ ) and appressorium (4.5 to $10.8 \%$ ), also with no significant difference between evaluation periods, except in the case of arbuscules that increased at 60 days compared the first observation at 30 days of incubation (Table 2). 
Table 2. Percentage of hyphae (H), vesicles (Ve), arbuscules (Arb), spores (Spo) and appressorium (Ap) of arbuscular mycorrhizal fungi in Paspalum millegrana evaluated after 30,60 and 90 days of culture of cultivation.

\begin{tabular}{|c|c|c|c|c|c|c|}
\hline Treatments $^{1}$ & $\begin{array}{c}\begin{array}{c}\text { Evaluation } \\
\text { (days) }\end{array} \\
\end{array}$ & $\begin{array}{c}\mathrm{H} \\
(\%) \\
\end{array}$ & $\begin{array}{l}\mathrm{Ve} \\
(\%)\end{array}$ & $\begin{array}{l}\text { Arb } \\
(\%)\end{array}$ & $\begin{array}{l}\text { Spo } \\
(\%)\end{array}$ & $\begin{array}{l}\mathrm{Ap} \\
(\%)\end{array}$ \\
\hline \multirow[t]{3}{*}{ Control } & 30 & $51.1 \mathrm{a}^{2}$ & $20.0 \mathrm{a}$ & $0.0 \mathrm{a}$ & $8.9 \mathrm{a}$ & $0.0 \mathrm{a}$ \\
\hline & 60 & $40.0 \mathrm{a}$ & $13.3 \mathrm{a}$ & $0.0 \mathrm{a}$ & $6.7 \mathrm{a}$ & $0.0 \mathrm{a}$ \\
\hline & 90 & $20.0 \mathrm{a}$ & $0.0 \mathrm{a}$ & $0.0 \mathrm{a}$ & $0.0 \mathrm{a}$ & $0.0 \mathrm{a}$ \\
\hline \multirow[t]{3}{*}{ Native $(\mathrm{N})$} & 30 & $72.4 \mathrm{a}$ & $15.2 \mathrm{a}$ & $0.0 \mathrm{~b}$ & $10.5 \mathrm{a}$ & $2.0 \mathrm{~b}$ \\
\hline & 60 & $36.7 \mathrm{ab}$ & $19.6 \mathrm{a}$ & $19.4 \mathrm{a}$ & $21.8 \mathrm{a}$ & $2.5 \mathrm{ab}$ \\
\hline & 90 & $30.7 \mathrm{~b}$ & $19.1 \mathrm{a}$ & $18.2 \mathrm{a}$ & $20.6 \mathrm{a}$ & $11.5 \mathrm{a}$ \\
\hline \multirow[t]{3}{*}{$\mathrm{N}+$ UFLA05 } & 30 & $50.8 \mathrm{a}$ & $18.7 \mathrm{ab}$ & $0.0 \mathrm{~b}$ & $21.2 \mathrm{a}$ & $9.3 \mathrm{a}$ \\
\hline & 60 & $22.7 \mathrm{a}$ & $32.5 \mathrm{a}$ & $21.6 \mathrm{a}$ & $6.7 \mathrm{a}$ & $16.6 \mathrm{a}$ \\
\hline & 90 & $54.5 \mathrm{a}$ & $5.7 \mathrm{~b}$ & $8.7 \mathrm{ab}$ & $27.8 \mathrm{a}$ & $3.3 \mathrm{~b}$ \\
\hline \multirow[t]{3}{*}{$\mathrm{N}+$ UFLA351 } & 30 & $61.4 \mathrm{a}$ & $0.0 \mathrm{~b}$ & $0.0 \mathrm{~b}$ & $18.6 \mathrm{a}$ & $0.0 \mathrm{~b}$ \\
\hline & 60 & $31.9 \mathrm{a}$ & $16.5 \mathrm{a}$ & $17.8 \mathrm{a}$ & $19.7 \mathrm{a}$ & $14.0 \mathrm{a}$ \\
\hline & 90 & $39.4 \mathrm{a}$ & $10.5 \mathrm{ab}$ & $9.0 \mathrm{ab}$ & $37.1 \mathrm{a}$ & $4.0 \mathrm{ab}$ \\
\hline \multirow[t]{3}{*}{$\mathrm{N}+$ UFLA372 } & 30 & $28.7 \mathrm{a}$ & $10.9 \mathrm{~b}$ & $0.0 \mathrm{~b}$ & $20.4 \mathrm{a}$ & $0.0 \mathrm{~b}$ \\
\hline & 60 & $15.0 \mathrm{a}$ & $42.3 \mathrm{a}$ & $16.7 \mathrm{a}$ & $5.0 \mathrm{a}$ & $2.0 \mathrm{a}$ \\
\hline & 90 & $24.4 \mathrm{a}$ & $41.2 \mathrm{a}$ & $0.0 \mathrm{~b}$ & $30.4 \mathrm{a}$ & $4.0 \mathrm{~b}$ \\
\hline \multirow[t]{3}{*}{$\mathrm{N}+$ UFLA401 } & 30 & $42.9 \mathrm{a}$ & $11.4 \mathrm{~b}$ & $0.0 \mathrm{a}$ & $25.7 \mathrm{a}$ & $0.0 \mathrm{a}$ \\
\hline & 60 & $31.8 \mathrm{a}$ & $16.9 \mathrm{ab}$ & $9.0 \mathrm{a}$ & $32.4 \mathrm{a}$ & $10.0 \mathrm{a}$ \\
\hline & 90 & $42.4 \mathrm{a}$ & $34.8 \mathrm{a}$ & $2.5 \mathrm{a}$ & $15.4 \mathrm{a}$ & $5.0 \mathrm{a}$ \\
\hline \multirow[t]{3}{*}{ Mixture } & 30 & $34.8 \mathrm{a}$ & $9.4 \mathrm{a}$ & $0.0 \mathrm{~b}$ & $11.4 \mathrm{a}$ & $4.4 \mathrm{a}$ \\
\hline & 60 & $26.3 \mathrm{a}$ & $27.1 \mathrm{a}$ & $13.6 \mathrm{a}$ & $22.2 \mathrm{a}$ & $10.8 \mathrm{a}$ \\
\hline & 90 & $51.0 \mathrm{a}$ & $23.5 \mathrm{a}$ & $8.6 \mathrm{ab}$ & $14.4 \mathrm{a}$ & $2.5 \mathrm{a}$ \\
\hline
\end{tabular}

${ }^{1}$ Treatments: Control (without AMF); Native (N): native microbial inoculant; N + UFLA05: native + UFLA05 G. albida; N + UFLA351: native + UFLA 351 R. clarum; N + UFLA372: native + UFLA372 C. etunicatum; N + UFLA401: native + UFLA401 A. morrowiae; e mixture - all isolates UFLA; ${ }^{2}$ Means followed by the same lower case letter (column) and upper case (line) do not differ statistically by the Tukey test at $5 \%$ probability.

In general, the colonization of P. millegrana was characterized by the presence of hyphae, vesicles, spores, arbuscules and appressorium, depending on the fungus-plant interaction. Among these structures, the presence of arbuscules is the most important, because it is responsible for the symbiosis itself (MIRANDA, 2008). García and Mendonza (2008) reported that the mycorrhizal colonization of $P$. vaginatum was arbuscular in spring, but vesicular in summer, which may have influenced the percentage of arbuscules and vesicles observed during mycorrhizal colonization, since the bioassay was implanted at the end of spring and concluded in summer, depending on the fungus-plant interaction. In addition, these authors observed that the colonization by hyphae is more significant in Poaceae than in Fabaceae, which corroborates the increased hyphae presence (20 to $72.4 \%$ ) observed in the root fragments of $P$. millegrana (Table 3).

The presence of hyphae in the AMF-plant association can release a glomalin, a known glycoprotein that facilitates the hyphae in the formation of soil aggregates, and thus is important in soil conservation (RUBIN; STÜRMER, 2015). Hyphae also contribute to increased water and nutrient uptake, which are important in survival and in the carbon metabolism plants
(DUPONT et al., 2015).

The appressorium and arbuscules observed in all the treatments demonstrate that there is symbiotic interaction between $P$. millegrana, the native arbuscular mycorrhizal fungi and UFLA. These structures are essential for the symbiosis between $\mathrm{AMF}$ and the plant, because the appressorium are modified hyphae with the added functionality of adhering to the surface of the root and initiate root colonization, while the arbuscules are structures responsible for the transfer of nutrients between the fungus and the plant (MIRANDA, 2008).

It should be emphasized that the mycorrhizal colonization of a plant species cannot always positively influence the vegetative development of the host plant or vice versa (GRAHAM; LINDERMAN; MENGE, 1982). The colonization observed in the control and the presence of dark septate endophytic fungi may mask the effect of native inoculants and UFLA in the development of P. millegrana. The inoculation of $P$. millegrana with native + UFLA351 and native + UFLA372 resulted in shorter plants compared to that in other treatments. However, this result did not interfere in the dry shoot mass, dry root mass, root length and root volume, when compared to the other mycorrhizal treatments and control (Table 3). 
Table 3. Plant height (PH), dry shoot mass (DSM), dry root mass (DRM), root length (RL), root volume (RV) and number of tillers (NT) of Paspalum millegrana inoculated with native microorganisms and arbuscular mycorrhizal fungi after 90 days of cultivation.

\begin{tabular}{lcccccc}
\hline \multicolumn{1}{c}{ Treatments } & $\begin{array}{c}\text { PH } \\
(\mathrm{cm})\end{array}$ & $\begin{array}{c}\text { DSM } \\
(\mathrm{g})\end{array}$ & $\begin{array}{c}\text { DRM } \\
(\mathrm{g})\end{array}$ & $\begin{array}{c}\text { RC } \\
(\mathrm{cm})\end{array}$ & $\begin{array}{c}\text { RV } \\
(\mathrm{L})\end{array}$ \\
\hline Control & $69.4 \mathrm{a}^{2}$ & $1.6 \mathrm{a}$ & $0.5 \mathrm{a}$ & $18.6 \mathrm{a}$ & $0.013 \mathrm{a}$ & $1.3 \mathrm{ab}$ \\
Native (N) & $67.4 \mathrm{a}$ & $1.1 \mathrm{a}$ & $0.5 \mathrm{a}$ & $18.0 \mathrm{a}$ & $0.010 \mathrm{a}$ & $1.6 \mathrm{a}$ \\
N + UFLA05 & $68.2 \mathrm{a}$ & $0.7 \mathrm{a}$ & $0.8 \mathrm{a}$ & $18.9 \mathrm{a}$ & $0.007 \mathrm{a}$ & $0.3 \mathrm{~b}$ \\
N + UFLA351 & $51.6 \mathrm{~b}$ & $0.9 \mathrm{a}$ & $0.5 \mathrm{a}$ & $20.7 \mathrm{a}$ & $0.010 \mathrm{a}$ & $0.6 \mathrm{ab}$ \\
N + UFLA372 & $43.8 \mathrm{~b}$ & $0.9 \mathrm{a}$ & $0.4 \mathrm{a}$ & $19.7 \mathrm{a}$ & $0.007 \mathrm{a}$ & $1.0 \mathrm{ab}$ \\
N + UFLA401 & $47.8 \mathrm{~b}$ & $08 \mathrm{a}$ & $0.3 \mathrm{a}$ & $18.5 \mathrm{a}$ & $0.007 \mathrm{a}$ & $0.3 \mathrm{~b}$ \\
Mixture & $64.4 \mathrm{a}$ & $1.0 \mathrm{a}$ & $0.3 \mathrm{a}$ & $19.8 \mathrm{a}$ & $0.006 \mathrm{a}$ & $0.4 \mathrm{~b}$ \\
\hline CV $(\%)$ & 25.0 & 37.5 & 39.7 & 17.6 & 32.9 & 46.1 \\
\hline
\end{tabular}

${ }^{1}$ Treatments: Control (without AMF); Native (N): native microbial inoculant; N + UFLA05: native + UFLA05 G. albida; N + UFLA351: native + UFLA $351 R$. clarum; N + UFLA372: native + UFLA372 C. etunicatum; $\mathrm{N}+$ UFLA401: native + UFLA401 A. morrowiae; e mixture - all isolates UFLA; ${ }^{2}$ Means followed by the same lower case letter (column) and upper case (line) do not differ statistically by the Tukey test at $5 \%$ probability.

Tiller emergence in $P$. millegrana was significantly higher with the native inoculant than with the treatment with native inoculants + UFLA05, native + UFLA401 and a mixture, but with no difference in the control, native + UFLA351 and native + UFLA372 (Table 3 ). The number of tillers could not be correlated to the mycorrhizal colonization of $P$. millegrana in all the treatments. Likewise, Cavagnaro et al. (2014) confirmed that the number of tillers in $P$. dilatatum was not influenced by the use of AMF isolates, despite the higher tiller biomass than that of the control

The mycorrhizal colonization of $P$. millegrana in the control, native, native + UFLA05 and native + UFLA401 treatments did not correlated to the biomass parameters (dry mass, root length and root volume). However, in the mixture treatment, a positive correlation between mycorrhizal colonization and dry shoot matter $(\mathrm{r}=0.90,0.1 \leq \mathrm{p}$ $<0.05)$ and root length $(r=0.93,0,1 \leq p<0.05)$ could be observed.

In the native treatment + UFLA351 there was no correlation between the colonization and the biomass variables, but the root volume was positively correlated to the dry root mass $(r=0.97, p$ $<0.01)$ and dry shoot mass $(r=0.93,0.1 \leq \mathrm{p}<0.05)$. In the native treatment + UFLA372 there was a positive correlation only between the root volume and root length $(\mathrm{r}=0.92,0.1 \leq \mathrm{p}<0.05)$, and between root volume and plant height $(\mathrm{r}=0.91 ; 0.01$ $\leq \mathrm{p}<0.05)$ of $P$. millegrana.

The increase of the root volume of $P$. millegrana with native + UFLA351 and native + UFLA372 is linked to the intense formation of fine roots, which increase the surface area for water and nutrient absorption, as observed for other species of Paspalum (CHANNABASAVA; LAKSHMAN; MUTHUKUMAR, 2015; CAVAGNARO et al., 2014).

Considering the mycorrhizal dependence, there was a $46 \%$ increase in the dry root mass of $P$. millegrana with native + UFLA05 and $28 \%$ in the native treatment + UFLA351 when compared to that in the control. This indicates that P. millegrana is responsive to inoculation of these microorganisms (Figure 1).

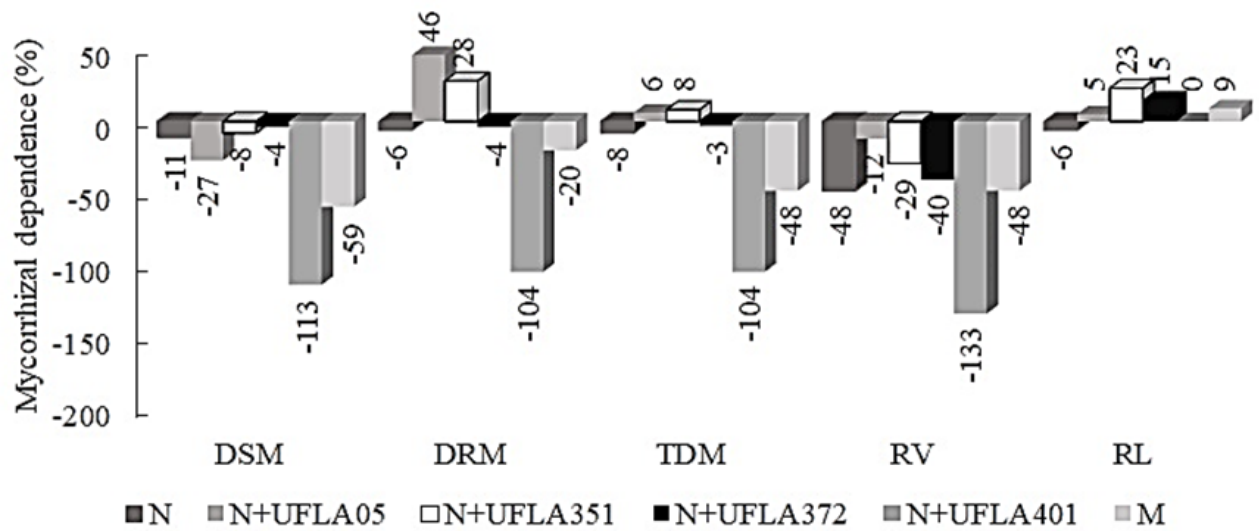

Figure 1. Mycorrhizal dependence of Paspalum millegrana inoculated with native microorganisms and arbuscular mycorrhizal fungi* for dry shoot mass (DSM), dry root mass (DRM), total dry matter (TDM), root volume (RV) and root length (RL) after 90 days of cultivation ${ }^{*}$ Control (without AMF); Native (N): native microbial inoculant; $\mathrm{N}+\mathrm{UFLA05}$ : native + UFLA05 G. albida; N + UFLA351: native + UFLA 351 R. clarum; N + UFLA372: native + UFLA372 C. etunicatum; N + UFLA401: native + UFLA401 A. morrowiae; e M - mixture of all isolates UFLAs. 
On the other hand, $P$. millegrana was not responsive to the use of mycorrhizal isolates for some of the attributes, such as dry shoot mass, total dry mass, root volume and root length (Figure 1), since they indicated mycorrhizal dependence to be below 25\% (MACHINESKI; BALOTA; SOUZA, 2011). Cavagnaro et al. (2014) found that the AMFgrass members' interaction of tropical climate, for instance, with Panicum coloratum, resulted in an increase of 202 to $206 \%$ of the dry biomass when compared to that in the control. Whereas, $P$. dilatatum only had an increase of $98 \%$ with mycorrhizal addition in relation to that in the control. According to these authors, the increase of the biomass of poplars plant inoculated with AMF is probably correlated with to the high colonization, which varied from 63 to $80 \%$, depending on the grass species.

In this study, mycorrhizal colonization was observed in the control treatment. It is possible that such colonization may have masked the effects of the native and native + UFLA isolates on the vegetative development of $P$. millegrana. Graham, Linderman and Menge (1982) observed a lack of correlation between mycorrhizal efficiency and colonization, such that, low colonization may favor the biomass formation of the plant. In addition, the presence of dark septate endophytes in all treatments, except the native, may have stimulated the development in the control and/or inhibited the development of UFLA in those treatments containing the native AMF + UFLA. Since, Yan et al. (2015) reported that endophytic fungi may stimulate or inhibit the microbial population, depending on the fungi-plant interaction. In general, the colonization of $P$. millegrana by native AMF and the presence of dark septate endophytic fungi may be responsible for the survival and development of $P$. millegrana in the field.

\section{CONCLUSIONS}

P. millegrana is colonized by AMF and dark septate endophytes.

The mycorrhizal colonization of $P$. millegrana influences the sporulation of $\mathrm{AMF}$ isolates depending on the fungi-plant interactions.

Tiller emission of $P$. millegrana is not correlated to mycorrhizal colonization.

$P$. millegrana is responsive to native inoculant + UFLA05 (Gigaspora albida) and native + UFLA351 (Rhizoglomus clarum).

The formation of fine roots observed in all treatments may contribute to the survival of $P$. millegrana under field conditions, probably due to the greater absorption of water and nutrients from the soil.

The mycorrhizal dependence evaluated based on dry root mass is a more precise indicator of the mycorrhizal activity to estimate biomass rather than he dry shoot mass and the total dry mass as described in the literature.

\section{REFERENCES}

AUGÉ, R. M. Water relations, drought and vesicular -arbuscular mycorrhizal symbiosis. Mycorrhiza, v. 11, n. 1, p. 3-42, 2001.

AZEVEDO, J. L. Microorganismos endofíticos. In: MELO, I. S.; AZEVEDO, J. L. (Eds.). Ecologia Microbiana. Jaguariúna: Embrapa, 1998, cap. 4, p. 117-137.

BARROW, J. R.; OSUNA, P. Phosphorus solubilization and uptake by dark septate fungi in fourwing saltbush, Atriplex canescens (Pursh) Nutt. Journal of Arid Environments, v. 51, n. 7, p. 449459, 2002.

CARAMASCHI, G. M. C. L. et al. The superior resprouting perfomance of exotic grass species under different environmental conditions: the study case of Paspalum atratum (Swallen) and Urochloa brizantha (Hochst. Ex. A. Rich-Stapf.). Theoretical and Experimental Plant Physiology, v. 28, n. 3, p. 178-285, 2016.

CARNEIRO, R. F. V. et al. Fungos micorrízicos arbusculares como indicadores da recuperação de áreas degradadas no Nordeste do Brasil. Revista Ciência Agronômica, v. 43, n. 4, p. 648-657, 2012.

CAVAGNARO, R. A. et al. Screening of biomass production of cultivated forage grasses in response to mycorrhizal symbiosis under nutritional deficit conditions. Japanese Society of Grassland Science, v. 60, n. 1, p. 178-184, 2014.

CHANNABASAVA, A.; LAKSHMAN, H. C.; MUTHUKUMAR, T. Fly ash mycorrhizoremediation through Paspalum scrobiculatum L., inoculated with Rhizophagus fasciculatus. Comptes Rendus Biologies, v. 338, n. 1, p. 29-39, 2015

CUI, H. et al. The combined effects of cover crops and symbiotic microbes on phosphatase gene and organic phosphorus hydrolysis in subtropical orchard soils. Soil Biology \& Biochemistry, v. 82, n. 1, p. 119-126, 2015.

DUPONT, P. Y. et al. Fungal endophyte infection of ryegrass reprograms host metabolism and alters development. New Phytologist, v. 208, n. 4, p. 1227 $-1240,2015$.

GARCÍA, I. V.; MENDOZA, R. E. Relationships 
among soil properties, plant nutrition and arbuscular mycorrhizal fungi-plant symbioses in a temperate grassland along hydrologic, saline and sodic gradientes. FEMS Microbiology Ecology, v. 63, n. 3 , p. $359-371,2008$

GERDEMANN, J. W.; NICOLSON, T. H. Spores of mycorrhizal endogone species extracted from soil by wet-sieving and decanting. Transactions of British Mycological Society, v. 46, n. 2, p. 235-244, 1963.

GIOVANNETTI, M.; MOSSE, B. An evaluation of techniques for measuring vesicular arbuscular mycorrhizal infection in roots. New Phytologist, v. 84 , n. 3, p. 489-500, 1980.

GRAHAM, J. H.; LINDERMAN, R. G.; MENGE, J. A. Development of external hyphae by different isolates of mycorrhizal Glomus spp. in relation to root colonization and growth of Troyer citrange. New Phytologist, v. 91, n. 1, p. 183-189, 1982.

HOLANDA, F. S. R.; ROCHA, I. P.; OLIVEIRA, V. $\mathrm{S}$. Estabilização de taludes marginais com técnicas de bioengenharia de solos no Baixo São Francisco. Revista Brasileira de Engenharia Agrícola e Ambiental, v. 12, n. 6, p. 570-575, 2008.

JALONEN, R. et al. Arbuscular mycorrhizal symbioses in a cut-and-carry forage production system of legume tree Gliricidia sepium and fodder grass Dichanthium aristatum. Agroforestry Systems, v. 87, n. 2, p. 319-330, 2013.

LONDE, P. R.; BITAR, N. A. B. Importância do uso de vegetação para contenção e combate à erosão em taludes do lixão desativado no município de Patos de Minas (MG). Revista Perquirere, v. 8, n. 2, p. 224249, 2011.

MACHINESKI, O.; BALOTA, E. L.; SOUZA, J. R. P. Resposta da mamoneira a fungos micorrízicos arbusculares e a níveis de fósforo. Semina: Ciências Agrárias, v. 32, n. 4, p. 1855-1862, 2011.

MACIEL, J. R.; ALVES, M. A família Poaceae na Serra de Itabaiana, Parque Nacional Serra de Itabaiana, Sergipe-Brasil. Revista Caatinga, v. 24, n. 3, p. 85-93, 2011.

MACIEL, J. R. M.; OLIVEIRA, R. C.; ALVES, M. Paspalum L. (Poaceae: Panicoideae: Paniceae) no estado de Pernambuco, Brasil. Acta Botânica Brasileira, v. 23, n. 4, p. 1145-1161, 2009.

MIRANDA, J. C. C. Cerrado: Micorriza Arbuscular - ocorrência e manejo. 1. ed. Planaltina, DF: Embrapa Cerrados, 2008. 169 p.
MONROY, H. J. et al. Influência de las coberturas em cultivos de cítricos sobre los hongos formadores de micorrizas arbusculares em Oxisoles del piedemonte Ilanero colombiano. Corpoica Ciencia Tecnología Agropecuaria, v. 14, n. 1, p. 53-65, 2013.

OLIVEIRA, C. O. et al. Paspalum (Poaceae) no Rio Grande do Norte, Brasil. Rodriguésia, v. 64, n. 4, p. 847-862, 2013.

RIBEIRO, K. G. et al. Isolamento, armazenamento e determinação da colonização por fungos "dark septate" a partir de plantas de arroz. Revista Agro@ambiente on-line, v. 5, n. 2, p. 97-105, 2011.

RUBIN, J. G. K. R.; STÜRMER, S. L. Potencial de inóculo micorrízico e importância do comprimento do micélio para agregação de solos de ambiente fluvial. Revista Brasileira de Ciência do Solo, v. 39 , n. 1, p. 59-68, 2015.

SANTOS, T. T.; VARAVALlO, M. A. Aplicação de microrganismos endofíticos na agricultura e na produção de substâncias de interesse econômico. Semina: Ciências Biológicas e da Saúde, v. 32, n. 2, p. 199-212, 2011.

UMA, E. et al. Tree species as hosts for arbuscular mycorrhizal and dark septate endophytes fungi. Journal of Forestry Research, v. 23, n. 4, p. 641$649,2012$.

YAN, J. F. et al. Do endophytic fungi grow thought their hosts systemically? Fungal Ecology, v. 13, n. 1, p. $53-59,2015$. 